\title{
Unexpected compliance? The implementation of the Defence and Security Procurement Directive
}

\begin{abstract}
When the member states of the European Union (EU) accepted the Defence and Security Procurement Directive, the expectation was that they would be able to retain a substantial amount of autonomy. During the implementation process, however, the members accepted the European Commission as a legitimate authority on how the Directive should be implemented. In this light, member states changed one specific policy issue, not addressed in the Directive: their offset policy. Addressing the role of the Commission in the Common Security and Defence Policy, this paper analyses three separate cases and finds that a cost benefit analysis cannot explain why these member states complied with nonlegally binding Guidance Notes issued by the Commission. The paper also explores the role of national civil servants seeking rule consistency and finds they acknowledged the authority of the Commission in prescribing new rules.
\end{abstract}

Keywords: Defence and Security Procurement Directive; European Commission; Guidance Notes; implementation; compliance; cost benefit analysis; bureaucracy

\section{Introduction}

The main understanding of the Common Security and Defence Policy of the European Union (EU) is that there is no role for a supranational institution in this policy field. However, by opting for a redefinition of the European defence procurement policy from intergovernmental to supranational, the Defence and Security Procurement Directive (DSPD or Defence Directive) represents a departure from this understanding (Official Journal of the European Union 2009). This particular Directive laid the foundation for an internal defence equipment market and was accepted following an initiative from the Commission. While recent studies have found a growing role for the Commission in this particular policy field (Strikwerda 2017; Weiss and Blauberger 2013), the (dominant) description of the CSDP is still intergovernmental (Sjursen 2011). This paper analyses the role of the Commission in the implementation phase of the Defence Directive. While the implementation process of EU directives is largely in the hands of the member states (Treib 2014; Mastenbroek 2007; Kaeding 2007), the Commission, through the publication of non-legally binding Guidance Notes on how to implement the Defence 
Directive, was able to shape this process. The publication of these notes has resulted in changes to member states' policies beyond what was already agreed upon in the DSPD.

That member states complied with a non-legally binding guidance note is both empirically and theoretically puzzling. First, because the specific Guidance Note on offsets addresses a controversial issue omitted in the Directive (Trybus 2014: 421): member states could not agree on this issue during the negotiations on the draft directive, so offsets were left out of the final draft. Second, rational choice theory expects actors only to comply with soft measures when coerced (Elster 1986; Dahl 1957: 203). The assumption is that actors comply when the cost of non-compliance is higher than the gain. Yet the non-legally binding guidance notes do not provide the Commission with any means of coercion. The question guiding this paper therefore is: why did the member states make a de facto policy change based on a non-legally binding Guidance Note from the Commission? Representing a case of European integration through soft measures, this paper speaks to both European compliance literature (Checkel 1999; Tallberg 2002; Mastenbroek 2005; Mendrinou 2007; Treib 2014; Batory 2016) and literature addressing the role of the Commission in European (defence) integration (Strikwerda 2017; Blauberger and Weiss 2013).

In order to examine why member states complied with a Commission Guidance Note, three member states are selected where compliance was considered to be unlikely: the UK, the Netherlands and Finland. The choice of member states is based on the legal obligation of all member states to actively transpose EU Directives into domestic law (Treib 2014: 6; Mastenbroek 2007; Kaeding 2007). In addition, compliance comes at a cost, as these states have an interest in retaining offset policy as a national matter. The United Kingdom (UK) is studied first. Given the country's large defence industry (Ministry of Defence 2010), it was not necessary for the UK to follow the guidance of a supranational institution in this policy field. Despite this, the UK was one of the first member states to implement the Directive (Statutory instruments 2011). The Netherlands and Finland are studied next. Both are smaller member states with defence industries that consist mainly of small and medium-sized enterprises (AIV 2005; Puolustusministeriö 2017) making offsets in particular more valuable to these countries. For Finland, the new European legislation posed serious challenges for the Finnish defence industry (Mikkola, Anteroinen, and Lauttamäki. 2013). For the Netherlands, the abolition of compensation policy was dependent on the existence of a fully open defence equipment market in which the Dutch industry can remain viable (AIV 2005). 
The dominant explanation of compliance in EU implementation (compliance) literature is that it is subject to the enforcement role of the Commission (Tallberg 1999; Treib 2014). Based on the powers attributed to the Commission (Article 258 TFEU), this paper first examines whether the member states calculated the risk of sanctions when revising their offset policy ${ }^{1}$ in light of a specific Guidance Note addressing this policy. Challenging such an expectation, previous research findings on the role of the Commission in the field of defence procurement emphasize how, for example, the UK believed the Commission's bark to be worse than its bite (Strikwerda 2017). A cost benefit analysis is therefore deemed insufficient to explain why member states complied. Other perspectives might complement the explanation of the member state actors assessing risk. For example, since implementation is the responsibility of civil servants, they may have felt an obligation to follow rules that eventually led to changes in the national offset policy.

The contribution of this paper is twofold. First, recent studies addressing offset policy change have focused on the Commission, finding that the Commission is an opportunistic enforcer (Weiss and Blauberger 2016), but the member states are not systematically studied. We therefore know what the Commission did, and why. However, after examining the actions of the member state actors we may have to change our assumptions of why member states complied. These assumptions lead in to the second contribution, since the dominant mechanism in the implementation literature, analytically speaking, is coercion. Yet this particular explanation seems insufficient in this case. This paper seeks to fill this analytical gap by applying an alternative explanation, which allows for the examination of the mechanism of rule following by actors (civil servants) in the implementation phase.

The following section discusses the transposition of the Defence Directive and the status of the Guidance Notes. The third section presents an analytical framework before the empirical data from the Netherlands, Finland and the UK are analysed. The final section of this paper discusses the implications of the findings.

\section{The European Commission and implementation guidance}

The formal role of the Commission in the transposition of EU Directives is the monitoring and enforcement of implementation and compliance (Tallberg 2002; Börzel 2003). Hence, in practice, the Commission assists member states to achieve correct implementation and future compliance (Sverdrup 2003; Steunenberg 2010). Informal 
assistance is rendered, for example, in the publication of implementation plans and guidance notes. During the transposition of the Defence Directive, the Commission organized six transposition workshops with member states (European Commission 2010; Weiss and Blauberger 2016) after which seven Guidance Notes were published. These Guidance Notes reflect the opinion of the Commission on the legal interpretation of certain exemptions in the Directive, are non-legally binding, and published on the website of the Commission (European Commission 2010; Weiss and Blauberger 2016).

The publication of Guidance Notes and the organization of transposition workshops are practices that are not applied to every single Directive. The publication of Guidance Notes during the implementation process of the Defence Directive by the Commission therefore raises several questions. First, why did the Commission choose to publish Guidance Notes during the implementation of the Defence Directive? Second, why did the member states revise their policy based on these notes from the Commission, after having previously accepted a contested Directive? Compliance with these guidance notes is even more puzzling and unexpected in the field of defence and security. Yet the Guidance Notes were never contested by the member states (Commission official, 8 January 2016), and one of the Guidance Notes triggered a de facto offset policy change (Trybus 2014: 421; Weiss and Blauberger 2016).

The publication of a specific Guidance Notes on offsets resulted in member states 'abolishing the respective rule or revised their legislation' (European Commission 2012; Weiss and Blauberger 2016; European Commission 2016). Offset policy was intentionally omitted in the Directive, because member states could not agree whether the practice should be abolished. Even though member states were against the inclusion of offsets in the Directive, and what is more, urged the Commission not to publish the Guidance Note, they nevertheless adjusted their national offset policies.

Table 1. Overview policy process

\section{Identifying change: Three member states}

Three examples of such a de facto change will be discussed. The main indicator of change is the recognition that offset use is only possible when justified as an essential national security interest (European Commission 2010). In these three cases, formal government guidelines and a new policy were introduced after 2010, to steer the future use of compensation policy (see Table 1). 
In the Netherlands, the government changed its offset policy into a new Industrial Participation policy (Tweede Kamer 2011 - 2012; Tweede Kamer 2012 - 2013; Eerste Kamer 2012-2013) and published a specific Defence Industry Strategy (DIS) in 2013, based on the Commission's interpretation. The strategy contains guidelines for the national Industrial Participation policy (Rijksoverheid 2013); aimed at the consolidation of policy choices of what the Dutch government regards an essential national security interest (Rijksoverheid 2013). These new documents contain policy guidelines for the circumstances in which compensation will be provided (applied).

In Finland, a special report by the Finnish ministry of Defence states that the practice of offsets has changed and the clause is no longer automatically included in defence acquisitions (Puolustusministeriö 2017). Prior to January 2012, no legislative provisions on Industrial Participation existed. The Rules on Industrial Participation in Defence Equipment and Procurement were adopted by the Ministry of Economic Affairs and Employment on 1 January 2012 (Työ- ja elinkeinoministeriö 2012). The Finnish rules follow the interpretation of the Commission, applying offsets on a case-by-case basis.

The United Kingdom had an open and voluntary Industrial Participation policy from 1990 to 2012, when it was abandoned (Matthews 2014). It was replaced by a new approach called the Defence and Security Industrial Engagement Policy (DSIEP) (House of Commons 2012-2013). In addition, because of the Commission's interpretation of offsets, the British offset office was closed (Matthews 2014: 86). The main policy guidelines, addressing how to protect the national industry, are outlined in the 2012 White Paper (Ministry of Defence 2012).

\section{Explaining change: Two perspectives}

This section introduces two different perspectives to account for the compliance of these three member states with the interpretation of the Commission on offsets. Addressing compliance with a Guidance Notes from the Commission in a policy area where the Commission is not expected to have a say, the focus in the section below is on the enforcement role of the Commission, in particular how actors perceived this role in relation to the Directive's implementation and their offset policy.

\section{Risk of sanctions}

Studies on the implementation of and compliance with EU legislation in member states ask why the members do not comply with EU Directives or are slow in transposing 
directives (Batory 2016; Versluis 2004; Kaeding 2006). Findings in the implementation literature indicate that the overwhelming power of the Commission, supported by the case law of the European Court of Justice (ECJ), forces member states into compliance (Andersen 2012; Mastenbroek 2005; Steunenberg 2010; Versluis 2004; Weiss and Blauberger 2016). The Commission's ability to enforce compliance rests on the powers derived from article 258 TFEU (Andersen 2012) which states that the Commission can instigate an infringement procedure against a member state when the Commission 'considers that a Member State has failed to fulfil an obligation under the Treaties' (Official Journal of the European Union 2012). While the Guidance Notes are not legally binding per se, the Commission's power to start litigation procedures against a member state for not complying with EU legislation, waves the red flag of possible sanctions against faltering member states during the implementation of the DSPD. ${ }^{2}$

It is therefore likely that during the implementation process this risk was calculated by the member states. This assumption is in line with the propositions of the rational choice perspective, which assumes that actors make cost benefit calculations that drive action. Actors, in their calculations, take heed of self-interest and aim to maximize utility; the theory predicts that preferences remain fixed over time (Elster 1986). In this case, actors in the Netherlands, Finland and the UK have arguably made strategic cost benefit calculations, in response to the future risk of a sanction (Chayes and Chayes 1993, 187; Checkel 1999: 2; Treib 2014: 11). It can therefore be hypothesized that the UK, the Netherlands and Finland did in fact change the national offset policy, because they expected non-compliance to lead to future sanctions from the Commission.

In order to find support for this hypothesis, we need to determine whether officials in Finland, the Netherlands and the UK regard the Commission as an actor in this policy field with the potential to start infringement procedures. Second, actors are expected to emphasize the unacceptable risk of not complying. This manifestation of risk can be strengthened by finding whether the member states received what is known as a 'first warning' from the Commission during the period, or if court cases had been filed against these member states in the 2009-2013 period.

\section{In the hands of the bureaucracy}

The beginning of this paper pointed to statements by UK officials according to which threats by the Commission would not determine policy making in the field of defence procurement. That de facto offset policy did in fact change during the implementation 
phase can be explained by other mechanisms than the cost benefit calculations undertaken by member state officials. As the implementation of EU Directives lies mainly in the hands of the member states, it is likely that national administrations were in charge during the transposition. I draw on the logic of appropriateness to examine whether the role of these civil servants and the rules they wished to follow were a determinate factor in changing the policy de facto policy change (March and Olsen 1989). This perspective allows me to analyse rule-based action during the implementation and examine the extent to which the mechanism can account for compliance.

The basic understanding of the logic of appropriateness is that the actions of actors are context based (March and Olsen 1989). Consequently, actors, in (political) institutions, will follow rules and procedures due to a sense of duty (Olsen 2007). These rules and routines create coherence and give 'clear principles of division of labour' (March and Olsen 2011). The institutional setting and how it shapes the identity of actors in these institutions are hence seen as a separate explanatory factor (Eriksen 1999). Rationality follows from the conviction that an action is believed to be right when it is congruent with the identity of the actor. Following these theoretical assumptions, it is likely that civil servants will seek internal consistency among rules (March and Olsen 2009: 8).

The hypothesis following from this approach is that national offset policy was changed in the Netherlands, Finland and the UK because the Guidance Note created the necessary coherence and clarity, which echoed with the general concerns of rule consistency in the civil service. To see whether this hypothesis can explain the de facto policy change in these member states, I consider the following empirical manifestations. First, I examine which actors dealt with the implementation process. In other words, I may find that civil servants in the national departments of, for example, the ministries of defence were in charge of the implementation process. Second, the substance of the Guidance Note will be examined to establish whether Guidance Note created rule consistency, or to which principles or rules the note might have spoken. What I expect to find is that these national actors will confirm or deny whether they felt an obligation to follow the Commission's interpretation, based on the alignment of offset policy with existing (European) legislation or principles. 


\section{Data and Method}

Data collected from the Netherlands, Finland and the UK consist of primary documents on the Defence Directive produced between 2009 and 2013. These documents comprise official statements and reports from the national departments in charge of implementation. The main source of data is the semi-structured interviews undertaken with officials (Beach and Brun Pedersen 2013), insofar as the workshops and informal negotiations on which the paper draws cannot be traced in formal documents. Semistructured interviews were conducted with member state and Commission officials who took part in the informal workshops and meetings of member states and the Commission in 2010. In the Netherlands, I spoke to officials at departments in both the Ministry of Economic Affairs and Ministry of Defence, given that the implementation of the Defence Directive was in the hands of both these departments. In the UK, I interviewed officials at the Ministry of Defence only, in particular, at the Department of Defence Equipment and Support. Interviews in Finland were also conducted with officials in both the Ministry of Economic Affairs and Ministry of Defence.

Explaining the dependent variable, de facto policy change, based on a non-legally binding guidance note, can be achieved if member states can be found to have accepted the interpretation of the Commission given the high cost of non-compliance. The high cost is assumed to have been affixed to the possible risk of future sanctions. Second, in order to substantiate whether the Guidance Note created rule clarity and consistency, and civil servants had an inherent wish to follow these rules, I would expect to find that actors changed the views during the implementation process and that the Guidance Note reframed offset policy in light of existing legislation. The method applied in this paper is known as process tracing (Beach and Pedersen 2013: 14; Bennett and Checkel 2014), allowing for the examination of the empirical data and trace mechanisms. It also allows me to determine whether the cost benefit calculation mechanism or rule following can explain the compliance with a non-legally binding guidance note.

\section{Compliance with a non-legally binding guidance note}

Following the analytical framework introduced above, the three cases will be analysed to identify whether concern for sanctions can explain why these member states followed a non-legally binding guidance note from the Commission during the implementation of the Defence Directive. 


\section{Based on risk avoidance?}

The publication of Guidance Notes, and the involvement of the Commission during the implementation phase, was perceived by officials as an attempt on the part of the Commission to help the member states understand how the Directive should be applied (British official, 21 January 2015; 19 January 2015; Dutch officials, 18 February 2015). The Guidance Notes have had a significant impact on the use of the Directive by both European governments and European defence industry (Trybus 2014; ASD Official, January 2016). In the defence industry, the lawyers are all aware of the guidance notes, 'they know it by heart' (Commission official, 8 January 2015). While officials (or member states) may not follow these interpretations in every case, the Guidance Notes 'provide insight in the Commissions interpretation, and you have an idea of what the Commission would think in the case of something [Court case] (Commission official, 8 January 2016).

Actors also characterize these transposition workshops as an attempt of the Commission to create a common understanding of the legal interpretation: 'to aid the member state authorities in to transpose this Directive into national law' (Commission official, 8 January 2015; Council of the European Union 2013). 'We knew in the end of the day, what they wrote up was their interpretation (...) would be likely to be what the European Court would decide was their interpretation' (British official, 19 January 2015)

The Commission's interpretations were not lightly accepted, however, and there were vigorous arguments with the Commission about sensitive issues during these workshops. Much of the anger was directed at the Commission, because it seemed to have no idea of the impact their interpretations might have on the practice of the Directive (British official, 19 January 2015). However, officials also acknowledge that it would be good to reach consensus: it was considered important not to leave anything unclear: 'we do not want it as an issue' (British official, 21 January 2015).

(In one of the workshops) there was an issue [offsets] where all twenty-seven member states were against what the Commission was doing, and even the EDA joined in. All 27 of us, and EDA practically screaming at the Commission: 'You are here to serve us, if you are not serving us, why are you here?' They still, 'No, we think it is this'. (British official, 19 January 2015)

In the case of the UK, it is important first to remember the country is one of the leading defence exporters in Europe (Ministry of Defence 2010) and is therefore less dependent on defence integration than other member states. Although the UK has constantly been in 
favour of an open defence equipment market (House of Commons 2011), its policy is also very much focused on protecting the small and medium-sized enterprises in the country. While the British government aims to make sure the defence industry in the UK benefits from an open market, it should not be at the expense of losing autonomy (British official, January 2015).

The Government have sought to engage proactive with the Commission's taskforce, not least to ensure that any Commission strategy does not impinge on issues that are within, and should remain within, national competence. Defence is primarily a national sovereignty issue and it is not for the Commission to try to dictate change. (House of Commons 2013)

It was important, British officials said, to take part in the transposition workshops in 2010, because 'it would be good to reach consensus with the Commission'. The main goal was to clarify issues during the implementation phase, thereby making sure that the use of certain exemptions would not become an issue in the future (British official, 21 January 2015; 19 January 2015).

On the issues of offsets in particular, the British asked the Queen's Council for advice during the implementation process. This advice resulted in the creation of an industrial engagement policy (British official, 21 January 2015). In addition to certain exemptions in the Directive, UK officials reserved their position during the workshops when the Guidance Notes were presented (British official, 21 January 2015).

By the time you talk about the interpretation of something, you have both signed on the dotted line. So all you can do at that point is do what we did, write, and say thank you very much for all the workshops and everything. We appreciate the consultation but we find ourselves disagreeing on the following points and this is why. And so it is just putting a mark to say so when we get caught we refer to this (British official, 19 Jan 2015; see also Dutch official 18 February 2015)

These reservations made by British officials were meant to prevent future sanctions, or were such a sanction to be levied, they would be able to refer to their reservations on certain issues: 'because our legal interpretation is not the same as theirs' (British official 19 January 2015)

Both British and Dutch officials say the Commission's Guidance Note led to the creation of defence strategies that would reflect and clarify the future use of the Directive and offsets (Dutch official, 29 May 2015). These documents, a Swedish legal adviser 
explained, could then be used to clarify what the national security interest would be and could be used as proof in the future (Swedish official, 16 January 2015).

During the negotiations on the draft Directive, the Dutch government had been in favour of a specific provision on offsets, which was blocked by the other member states (British official 21 January; French official 14 January 2015; Dutch official 18 February 2015). After the publication of the Guidance Note and the revision of Dutch offset policies, the automatism of applying compensation was abandoned (Eerste Kamer 2013). After 2013, the Ministry of Economic Affairs explains that such an IP requirement is used, 'in case someone [the Commission] will ask critical questions, we can emphasize that this was to protect an essential national security interest' (Dutch official, 29 May 2015, author's translation). The Dutch government uses the Defence Industry Strategy as a strategic document to explain to the Commission what it is that constitutes an essential national security interest, and to prevent the Commission from taking action against infringements on this particular issue.

The risk of a future sanctions was a concern during this period, at the same time as the protection of national industry remained a major priority. The Dutch parliament passed a resolution stating that article 346 should be used as often as possible because it would be in the interest of the Dutch industry (Tweede Kamer 2010-2011). The Dutch are willing to take a risk because 'so far we have not been taken to Court' for the way in which offsets are applied (Dutch official, 29 May 2015). 'We haven't been confronted with the judge, and we do not know - it is very uncertain - if it in the end will pass legal scrutiny' (Dutch official, 29 May 2015, author's translation). The department has adjusted the formulation of certain exemptions, and both departments (Dutch officials, 6 January and 24 February 2015) have reformulated priorities for the national industry. Finland has also acknowledged the note on offsets, but concluded that the opinion of the Commission is by no means legally binding; it is only the ECJ that can pronounce binding legal interpretations (Finnish official, 30 June 2017).

Did the Commission actually instigate legal procedures against these three member states? During the transposition phase of the Directive, the Netherlands received a letter from the Commission, a first warning before a possible Court case, for delays in implementation (Dutch official, 18 February 2015). As the delay was caused by the abrupt end of the first Rutte government in 2012 (Dutch official, 18 February 2015) it cannot explain the adjustment of the offset policy. The UK transposed the Directive on time (2011), but did receive a letter from the Commission addressing the delay in transposition 
in Gibraltar. In the case of Finland, a court case dealing with the erroneous use of article 346 TFEU (C-284/05) ended in 2009. The judgement did not, however, affect the transposition of the Directive or introduce national offset policies. Since these cases of legal scrutiny do not address offsets specifically, were likely caused by other political factors outside the transposition process, and do not suggest the use of coercion with regards to offsets, they cannot explain why these member states created a new policy for dealing with defence offsets.

Having addressed the cases of the Finland, the Netherlands and the UK, knowledge that the Commission has the ability to coerce these member states to comply cannot fully account for their de facto policy changes. While the implementation literature - and even recent studies addressing European offset policy - do apply such a perspective to explain integration, I find little evidence in its support. Officials in both in the UK and the Netherlands say the process of applying offsets now falls under article 346 TFEU, which makes it more difficult to use compensation when procuring defence material. Yet in the case of the Netherlands, it is evident that the market is not open yet, spurring willingness to take risks. Scrutiny also very much depends on the active enforcement role of the Commission. The strength of its willingness to actively enforce the Directive (and thereby offsets) remains, however, uncertain (Commission official, 8 January 2016). Whether the Commission would actually enforce the law cannot therefore be fully known. In particular, for the UK, preferences have not changed during the implementation phase. British officials were able to influence the interpretations of the Commission quite extensively during the implementation phase. Although their legal department has grown, officials say, they are still willing to take risks, even if it could lead to sanctions. Nor do officials seem to be convinced that the Commission will actually pursue enforcement. The proposition that actors are driven by cost benefit calculations does not, therefore, seem to hold in this case.

Alternatively, did these actors believe it made sense to follow the Guidance Note because it created rule consistency?

\section{In the hands of the bureaucracy?}

To answer whether the implementing civil servants played a crucial role in changing the offset policy for reasons of rule consistency, this section will first discuss the actors that were in charge during the implementation process. Subsequently, the extent to which the 
Guidance Note addressing offsets created rule clarity and coherence will be discussed. Finally, this section asks whether they followed the Guidance Note due to a sense of duty.

The implementation of the Directive was in the hands of the bureaucracy (British official, 21 January 2015). Officials at the departmental level became the formal contact for the Commission (Dutch official 29 May 2015). The work at the ministry level concentrated on trying to understand the implications of the Directive. For many member states, with the exception of the UK and France, it was only after 2009 that direct contact was established between Brussels (the Commission) and 'people that have knowledge about procurement' (Dutch official, 29 May 2015, author's translation; British official, 19 January 2015). The Commission got to work mainly with national departments (Dutch official, 6 January 2015). The implications of the Directive, especially for the smaller member states, therefore only became apparent during the implementation phase.

The process of implementation in the UK started swiftly after the Directive was adopted. First, the ministry appointed a specialist programme manager that would spur the implementation process (British official, 19 January 2015; 20 January 2015). The main goal was to implement the Directive soon as possible, even though it is usually not the Ministry of Defence, but the Cabinet Office, that deals with the implementation of EU Directives. During the implementation process this special appointee became the contact point between the lower levels in the defence procurement field (and security) and the Commission. Officials from the department of Defence Equipment and Support mainly were involved in the implementation of the Directive and they attended the meetings with the Commission.

In the Netherlands, both the Department of Military Production at the Ministry of Economic affairs and the Defence Material Organisation started to work together on the implementation. One of the main issues for the Dutch administration was that the Commission came with additional measures, which reflected a certain distrust on the side of the Commission of the Dutch (Dutch official, 18 February 2015).

Concerning the guiding principles of the Guidance Note on offsets, the Commission mention offsets already in the 2006 Interpretative Communication, arguing that while the use of compensation did not serve any essential security interest, it did serve an economic interest. According to the Commission, article 346 TFEU can therefore not be used as a basis for compensation. Misuse of this article to award compensation would adversely affect the conditions of competition in the internal market (European Commission 2006). Even though the Commission was quite specific on the use and 
misuse of the national offset policy of the member states, the member states themselves did not adjust their policies at this time.

In the Guidance Note published after the April 2010 workshop on subcontracting and offsets, the Commission called

such offset requirements [...] restrictive measures which go against the basic principles of the Treaty, because they discriminate against economic operators, goods and services from other Member States and impede the free movement of goods and service. Since they violate basic rules and principles of EU law, the Directive cannot allow, tolerate or regulate them. (European Commission 2010)

Furthermore, the Commission stated, the offset policy should be based on the same principles as reflected in the Directive. The use of compensation would then be seen to violate both the Directive (Article 4 DSPD) and primary EU law. The Commission, with the help of the Guidance Note, was thus able to clarify and create coherence in the interpretation of offset policy in light of existing legislation, the Directive, and primary law in the EU (Trybus 2014).

The Commission interpreted and clarified the policy in light of existing internal market regulations and the principle of non-discrimination. The principle of nondiscrimination prohibits member states (actors) on grounds of nationality to treat imported goods differently to domestic goods (Article 18 TFEU; European Commission 2010, 2). It is therefore a central part of the Internal Market and intimately linked to the free movement of goods between member states (Article 34 TFEU).

From interviews with member state officials, it becomes evident that this reframing and interpretation caught many national actors by surprise. To quote a Dutch official for instance: 'The strong emphasis the Commission has placed on the use of 346 and the pressure against offsets, we didn't realize that it would be so strong' (Dutch official, 29 May 2015). The workshops and Guidance Note constituted a process by which the member states learned about the guiding principles of the Directive.

In the case of the Netherlands, the Commission's interpretation and clarification justified the policy changes that took place during the transposition phase. After the publication of the Guidance Note, Dutch officials say, it became evident that the Commission was against offsets from an internal market perspective, because it encouraged discrimination (Dutch official, February 2015). Dutch officials realized they would have to change their offset practice; what we have now is a 'kind of lost of 
correction mechanism' (Dutch official, 18 February 2015). For the Dutch government, this principle of non-discrimination became the reason to adjust policy.

Accepting compensation for tenders that are part of the Directive would imply a breach of the non-discrimination principle. National manufacturers would profit based on their nationality. This would go against the Treaty [of the EU], but would also conflict with the Directive. [...] For this reason the government has, in an attachment, highlighted the instances in which compensation for certain contracts under the Directive are prohibited. (Tweede Kamer 2011-2012, author's translation)

A Dutch official, at the Ministry of Economic Affairs supports these findings in emphasizing that the guidance note is the interpretation of the Commission on how to act. 'If you do not act accordingly, then you are doing something that is not in line with how it should happen' (Dutch official, 18 February 2015, author's translation). Finnish officials, in addition, see the Guidance Notes from the Commission as aimed at clarifying certain provisions in the Directive. This guidance was then used "when found appropriate, in the detailed reasoning included in the Government Bill presented to the Parliament when drafting the national legislation' (Finnish official, 30 June 2017). This indicates that national officials followed the implementation guidance of the Commission based on the principle of non-discrimination from a sense of obligation. What changed during the implementation period was first the existence of a specific Directive based on the principles the member states had agreed on, and second, recognition by the member states of the authority and credibility of the Commission to aid member states in the Directive's implementation.

This section has discussed which actors were in charge during the implementation process in order to explain why these member states complied with a non-legally binding guidance note on offsets. The process was shown to be in the hands of bureaucrats in different departments of the ministries of defence and of economic affairs in these member states. Furthermore, as the Commission's Guidance Note framed the offset policy in terms of primary EU law and the accepted Directive, civil servants were inclined to maintain rule consistency and adjusted the policy thereafter. The Commission's Guidance Notes created a form of soft law, and were considered sufficiently legitimate to follow. 


\section{Concluding remarks}

The European Commission was able to accomplish policy change in (at least) three member states by publishing a non-legally binding Guidance Note on offsets during the implementation process of the Defence and Security Procurement Directive. This paper finds that the enforcement powers of the Commission cannot account on their own for this change. In asking how these member states came to abolish their offset policy, the paper finds that actors changed during the implementation process. The civil servants responsible for the implementation and transposition of the Defence Directive in the Netherlands, UK and Finland aimed for rule consistency. The main reason why bureaucrats followed the Commission's advice is that the Guidance Note framed offsets in the light of existing legislation and the already accepted Directive.

What are the implications of these findings? First, the study fills a gap in the compliance literature, which has never addressed the impact of Guidance Notes on member state implementation of directives. As the implementation literature has increasingly expanded (Treib 2014) and enhanced our knowledge of this part of the policy process, the informal procedures by which the Commission influences this part of policy phase is less well known.

Second, through its analysis of soft measures, this study highlights the Commission's ability to change and influence the defence and security policy of the European Union. The paper therefore complements the literature on the role of the Commission in the formulation of the Common Security and Defence Policy and of studies that have addressed developments in this area. As the evidence indicates, the Commission is able to guide member states in their interpretation of the law, and member state officials consider such interpretative guidance to be appropriate; in other words, they recognize the authority of the Commission to offer advice. This is surprising, not least because in this policy field, member states are expected to be driven primarily by national interest.

Finally, analytically, the paper makes use of a well-known distinction between the logic of consequences and logic of appropriateness, finding that the former cannot fully account for the de facto national policy change. Applying the logic of appropriateness to this case study gives us an opportunity to understand, analyse and strengthen our knowledge of different mechanisms than those based on strategic interest or expected risk. The findings of this paper therefore emphasize the significance of the role of civil servants in the implementation phase, but they also reveal a need to identify 
the reasons why these actors considered it appropriate to follow soft measures (Eriksen 1999).

\section{References}

Adviesraad Internationale Vraagstukken. 2005. Europese militair-industriële samenwerking, 30 september 2005 - nr 20. Accessed 6 March 2017. http://aivadvies.n1/66z/publicaties/adviezen/europese-militair-industriele-samenwerking

Andersen, S. 2012. The Enforcement of EU Law: The Role of the European Commission. Oxford, New York: Oxford University Press.

Batory, A. 2016. "Defying the Commission: Creative Compliance and Respect for the Rule of Law in the EU." Public Administration 94 (3): 685-699.

Beach, D. and R. Brun Pedersen. 2013. Process-Tracing Methods. Foundations and Guidelines, Ann Arbor: University of Michigan.

Bennett, A. and J.T. Checkel, eds. 2014. Process Tracing: From Metaphor to Analytic Tool. Cambridge: Cambridge University Press.

Blauberger, M. and M. Weiss. 2013. "If you can"t beat me, join me!' How the Commission pushed and pulled member states into legislating defence procurement. Journal of European Public Policy 20 (8): 1120-1138.

Börzel, T. 2003. "Guarding the Treaty: The Compliance Strategies of the European Commission." In: The State of the European Union. Law, Politics and Society. Volume 6, edited by T. Börzel and R.A. Cichowski. Oxford: Oxford University Press.

Chayes, A. and A.H. Chayes. 1993. "On Compliance." International Organization 47 (2): 175-205.

Checkel, J. 1999. "Why Comply? Social Learning and European Identity Change." International Organization 55 (3): 553-588.

Dahl, R. 1957. 'The Concept of Power', Behavioral Science 2 (3): 201-215.

Eerste Kamer der Staten-Generaal. 2012-2013. Implementation van Richtlijn 2009/81 EG van het Europees Parlement en de Raad van 13 juli 2009 betreffende coordinatie van de procedures voor het plaatsen door aanbestedende diensten van bepaalde opdrachten voor werken, leveringen en diensten op defensie- en veiligheidsgebied, en tot wijziging van richtlijnen 2004/17/EG en 2004/18/EG 
(Aanbestedingswet op defensie- en veiligheidsgebied), 32 768, 13 December 2012.

Eerste Kamer der Staten-Generaal. 2013. Jaarrapportage compensatiebeleid 2011-2013: algemeen. Bijlage 1 bij brief DGBI-TOP-MP/13101646. Accessed 12 November 2016.

https://www.eerstekamer.nl/overig/20131213/jaarrapportage_compensatiebeleid

Elster, J. 1986. Rational Choice. New York: New York University Press.

Erisken, E.O. 1999. 'Towards a Logic of Justification. On the Possibility of Post-National Solidarity', in: Organizing Political Institutions. Essays for Johan P. Olsen, eds M. Egeberg and P. Lægreid, 215 - 244. Oslo: Scandinavian University Press.

European Commission. 2006. Interpretative Communication on the application of Article 296 of the Treaty in the field of defence procurement, COM 2006/0779 final.

European Commission. 2010. Directive 2009/81 EC on the award of contracts in the fields of defence and security. Guidance Note Offsets.

European Commission. 2012. Report from the Commission to the European Parliament and the Council on the transposition of Directive 2009/81/EC on Defence and Security Procurement, COM (2012) 0565 final, 2 October 2012.

European Commission. 2016. Report from the Commission to the Parliament and the Council on the implementation of Directive 2009/81/EC on public procurement in the fields of defence and security, to comply with Article 73(2) of that Directive, COM(2016) 762.

European Commission. 2018. 'Defence Procurement: Commission opens infringement procedures against 5 Member States', European Commission Press Release, 25 January 2018. Accessed 15 March 2018. http://europa.eu/rapid/press-release_IP18-357_en.htm

House of Commons. 2011. EC Defence Equipment Directives, SN/IA/4640, 3 June 2011. House of Commons. 2012-13. (Defence Committee) Defence Acquisition. Seventh Report of Session 2012-13, Volume 1: Report, together with formal minutes, oral and written evidence. 5 February 2013. Accessed March 2017. https://www.publications.parliament.uk/pa/cm201213/cmselect/cmdfence/9/902. htm

House of Commons. 2013. Defence and Security Procurement, European Committee B, 28 January 2013. Accessed 25 September 2016. 
https://www.publications.parliament.uk/pa/cm201213/cmgeneral/euro/130128/1 30128s01.htm

Kaeding, M. 2006. 'Determinants of transposition delay in the European Union.' Journal of Public Policy 26 (3): 229 - 253.

Kaeding, M. 2007. Better Regulation in the European Union - Lost in Translation or Full Steam Ahead? The Transposition of EU transport directives across Member States. PhD diss., University of Leiden.

March, J. and J.P. Olsen. 1989. Rediscovering Institutions. The Organizational Basis of Politics. New York: Free Press.

March, J. and J.P. Olsen. 2009. 'The Logic of Appropriateness.' ARENA Working Paper, 04/09.

March, J. and J.P. Olsen. 2011. "The Logic of Appropriateness." In: The Oxford Handbook of Political Science, edited by R. Goodin, Oxford: Oxford University Press.

Mastenbroek, E. 2005. "EU compliance: Still a "black hole"?" Journal of European Public Policy 12 (6):1103-1120.

Mastenbroek, E. 2007. The Politics of Compliance. PhD diss., University of Leiden.

Matthews, R. 2014. "The UK offset model. From participation to engagement." Royal United Service Institute, Whitehall Report 1-14, July 2014.

Mendrinou, M. 2007. "Non-compliance and the European commission's role in integration", Journal of European Public Policy 3 (1): 1-22.

Mikkola, H., J. Anteroinen and V. Lauttamäki. 2013. "The changing European Defence Market. Will the new European defence market legislation be a game-changer for Finland?" FIIA Briefing Paper 123

Ministry of Defence. 2010. Equipment, Support, and Technology for UK Defence and Security: A consultation paper, December 2010. Accessed 13 March 2017. https://www.gov.uk/government/uploads/system/uploads/attachment_data/file/3 5916/cm7989_Eqpt_supp_tech_ukdef.pdf

Ministry of Defence. 2012. National Security through Technology: Technology, Equipment, and Support for UK Defence and Security, White Paper Cm8278, London.

Official Journal of the European Union. 2009. Directive 2009/81/EC of the European Parliament and the Council of 13 July 2009 on the coordination of procedures for the award of certain contracts, supply contracts and service contracts by 
contracting authorities or entities in the field of defence and security, and amending Directive 2004/17/EC and 2004/18/EC.

Official Journal of the European Union. 2012. Consolidated version of the Treaty on the Functioning of the European Union. Accessed 23 November 2016. http://eurlex.europa.eu/legalcontent/EN/TXT/PDF/?uri=CELEX:12012E/TXT\&from=EN

Olsen, J.P. 2007. "Understanding institutions and Logic of Appropriateness: Introductory Essay." ARENA Working Paper, 13 August 2007.

Puolustusministeriö. 2017. Industrial Participation in defence procurements. Accessed 16 March 2017. https://www.defmin.fi/files/3738/Industrial_participation_in_defence_procurem ents_PLM_2017_verkkojulkaisu.pdf]

Rijksoverheid. 2013. Defensie Industrie Strategie, 10 december 2013.

Sjursen, H. 2011. "Not so intergovernmental after all? On democracy and integration in European Foreign and Security Policy." Journal of European Public Policy 18 (8): 1078-1095.

Statutory instruments. 2011. No. 1848. Public Procurement. The Defence and Security Public Contracts Regulations 2011, 28 July 2011.

Steunenberg, B. 2010. "Is big brother watching? Commission oversight of the national implementation of EU directives." European Union Politics 11 (3): 359-380.

Strikwerda, J. 2017. "Sovereignty at stake? The European Commission's proposal for a Defence and Security Procurement Directive." European Security 26 (1): 1-18.

Sverdrup, U. 2003 "Compliance and styles of conflict management in Europe." ARENA Working paper $08 / 3$.

Tallberg, J. 1999. Making States comply. The European Commission, the European Court of Justice and the Enforcement of the Internal Market. Lund: Lund Political Studies.

Tallberg, J. 2002. "Paths to Compliance: Enforcement, Management and the European Union." International Organization 56 (3): 609-643.

Treib, O. 2014. "Implementing and complying with EU governance outputs." Living Reviews in European Governance 9 (1)

Trubek, D.M., M.P. Cottrell and M. Nance. 2005. 'Soft Law', 'Hard Law' and European integration: Toward a Theory of Hybridity', University of Wisconsin Legal Studies Research Paper No. 1002 
Trybus, M. 2014. Buying Defence and Security in Europe: The EU Defence and Security Procurement Directive in Context. Cambridge: Cambridge University Press.

Tweede Kamer der Staten-Generaal. 2010-2011. Vaststelling van de begrotingsstaten van het Ministerie van Defensie (X) voor het jaar 2011. Motie van het lid Ten Broeke C.S., 8 December 2010.

Tweede Kamer der Staten-Generaal. 2011-2012. Implementatie van Richtlijn 2009/81 EG van het Europees Parlement en de Raad van 13 juli 2009 betreffende coordinatie van de procedures voor het plaatsen door aanbestedende diensten van bepaalde opdrachten voor werken, leveringen en diensten op defensie- en veiligheidsgebied, en tot wijziging van richtlijnen 2004/17/EG en 2004/18/EG (Aanbestedingswet op defensie- en veiligheidsgebied), 18 November 2011.

Tweede Kamer der Staten-Generaal. 2012-2013. Implementatie van Richtlijn 2009/81 EG van het Europees Parlement en de Raad van 13 juli 2009 betreffende coordinatie van de procedures voor het plaatsen door aanbestedende diensten van bepaalde opdrachten voor werken, leveringen en diensten op defensie- en veiligheidsgebied, en tot wijziging van richtlijnen 2004/17/EG en 2004/18/EG (Aanbestedingswet op defensie- en veiligheidsgebied), 31 October 2012.

Työ- ja elinkeinoministeriö. 2012. Rules on industrial participation in defence equipment procurement in Finland. Accessed 16 March 2017. https://tem.fi/documents/1410877/2132272/Rules_on_industrial_participation_i n_defence_equipment_procurement_in_Finland_2012/bebb87bc-7758-44579b32-bb0ebbef7166

Versluis, E. 2004. Explaining Variations in Implementation of EU Directives (SSRN Scholarly Paper No. ID 626066). Rochester, NY: Social Science Research Network. Retrieved from http://papers.ssrn.com/abstract=626066

Weiss, M. and M. Blauberger. 2016. "Judicialized Law-Making and Opportunistic Enforcement: Explaining the EU's Challenge of National Defence Offsets." Journal of Common Market Studies 54 (2): 444-462. 
${ }^{1}$ Offsets are the return investment of a country that sells defence material to a foreign government. Consequently, the return investment stimulates the economy of the buying country (Trybus 2014; Weiss and Blauberger 2016).

${ }^{2}$ This enforcement is reflected in current cases against Denmark and the Netherlands (European Commission 2018) 